\title{
Reexamination of Parallel Foreign Exchange and Real Estate Markets, Inflation and Monetary Policy Nexus in Zimbabwe 1998-2007
}

\author{
Juniours Marire \\ Department of Economics and Economic History, Rhodes University, P. O. Box 94, Grahamstown, , South \\ Africa, 6140
}

The research is not financed

Abstract

History that is ignored is very vengeful. The paper tests the claim by the central bank governor, who presided over hyperinflation in 2004-2008, that inflation was mainly driven by speculation and shadow printing of money in the financial system. Mutually reinforcing corporate incest manifesting in the real estate sector, banking sector, parallel foreign exchange market and the Zimbabwe stock exchange underpinned hyperinflation dynamics before and during his term of office. Speculative activities in these sectors drove money supply growth, parallel exchange rate premium and so, inflation. Existing studies have not tested his hypothesis and summarily have dismissed it arguing that hyperinflation was a doing of the central bank's monetary indiscipline. Using ARDL models we establish long run relationships amongst the building materials price index, consumer price index, parallel exchange rate and broad money supply. We also find bidirectional causality between money supply and the consumer price index as well as between the building materials price index and money supply. We find causation running from building materials index to consumer price index; from parallel exchange rate to consumer price index; and from broad money to parallel exchange rate. Our findings, to a considerable extent, not only confirm the governor's argument, but also confirm existing narratives of monetary indiscipline in explaining hyperinflation.

Keywords: Reserve Bank of Zimbabwe, Gideon Gono, Inflation, Building Materials Index, CPI, Parallel Exchange rate, ARDL

DOI: $10.7176 / \mathrm{JESD} / 11-10-14$

Publication date:May $31^{\text {st }} 2020$

\section{Introduction}

Zimbabwe has continued to fall at the stumbling block, hyperinflation. Reasons for hyperinflation are varied and literature has suggested that monetary indiscipline is the bedrock of inflation dynamics in Zimbabwe. Excessive government consumptive spending financed through printing of money is the main driver. Literature also concedes that the parallel exchange rate played an important role in inflation expectations formation (Kararach \& Otieno, 2016; McIndoe-Calder, 2018). A number of works have used Quantity Theory of Money (QTM) based explanations to argue that inflation has been a monetary phenomenon mostly. However, in a context where they find bidirectional causality they still ignore that and invoke QTM based explanations. It is important to note that the QTM models assumes unidirectional causality from money supply to inflation. The moment bidirectional causality is established, QTM based explanations become problematic. The former governor of the central bank, Gideon Gono, claimed that scholars had turned a blind eye to the multifaceted nature of inflation drivers in Zimbabwe during his tenure. His argument suggested that inflation drivers were substantially driven by market indiscipline in addition to supply-side shocks because of failing agriculture after the chaotic land reform, underutilization of capacity, and irrational exuberance in financial, parallel foreign exchange and Zimbabwe stock markets (Gono, 2008). Corporate incest in the financial system saw shadow printing of money and abuse of quasifiscal facilities provided by the central bank (Gono, 2008). The verdict in academic circles, however, has remained resolute that it was monetary indiscipline by the central bank that underpinned inflation, of which an excellent review of hyperinflation in Zimbabwe making this point clearly is Kararach \& Otieno (2016). Chances of success in appealing against this verdict are considered non-existent. Some thinkers have argued that rent seeking and political manipulation of the central bank in the age of Mugabeism was, and continues to be, the fundamental problem (Dawson \& Kelsall, 2012; Ndlovu-Gatsheni, 2015). The game of political survival therefore dictated pillaging of the central bank and the end result was hyperinflation. The pillaging of the central bank also led to hysteria in parallel foreign exchange market and the Zimbabwe Stock Exchange. The collapse of aggregate supply, frequent droughts, persistent fuel shortages and ailing critical state-owned enterprises such as the power utility and railways largely because of militarization (Rupiya, 2011) were also considered important contributors.

Setting aside data quality and availability issues, the paper tests the central bank governor's claim that it was the trilateral relationship amongst parallel foreign exchange market, real estate market, and stock market that underpinned the hyperinflation inferno. We demonstrate in the paper that to a considerable extent the governor's claims have substance even though that does not confute the verdict that monetary indiscipline was also a major 
factor in the dynamics. We find, inflation inertia to be the most influential factor in the evolution of inflation. This suggests existence of adverse adaptive inflation expectations. This factor has not been highlighted in much of the discourses making rounds. We demonstrate existence of bidirectional causality between the real estate market price dynamics and broad money and between broad money and the consumer price index. We also show a unidirectional causal influence from the real estate market price dynamics to the consumer price index. Taken together, the pieces seem to demonstrate that governor's claim cannot be summarily dismissed. While the verdict that monetary indiscipline was the bedrock of hyperinflation might not be successfully appealed against in the constitutional court of academic opinion, new accomplices have also been found adding to this multifaceted inferno. The remainder of this section sketches the background and the research problem. Section 2 presents arguments from literature. Section 3 presents methods and data and section 4 presents results. Section five concludes the paper.

\subsection{Background}

The chaotic land reform (1999-2002) led to the collapse of export performance and foreign currency earning capacity (Chitiga \& Mabugu, 2008; Sachikonye, 2003). It also led to sustained collapse of aggregate supply (AS) and excessive informalization of the economy, with GDP falling by approximately $40 \%$ between 2000 and 2008 , and an increase in unemployment to over $70 \%$ (Noko, 2011). Similarly, under conditions of escalating parallel exchange rate premium and reliance on food imports, it is evident that supply side shocks emanating from the foreign exchange market, albeit parallel, played an important role of increasing the role of imported inflation in the evolution of inflation dynamics in Zimbabwe (Kararach \& Otieno, 2016). Kararach \& Otieno (2016) find evidence of sustained long run depreciation of the real parallel exchange rate between 1998 and 2008, evidence which points to an ever increasing role of imported inflation in the evolution of inflation dynamics in Zimbabwe given the importance of imports in filling the gap created by a collapse in domestic aggregate supply. The collapse of export performance created severe foreign currency shortages, which motivated government to institute foreign currency allocation mechanisms as well as compulsory export earning surrender requirements (Kiguel, Lizondo, \& O'Connell, 1997; Makochekanwa, 2007b). Government had to find ways of sourcing foreign currency for critical operations.

Mawowa \& Matongo (2010) directly link the printing of money by the central bank to buy highly scarce foreign currency to the escalation of parallel market exchange rates in Zimbabwe. The burgeoning of cross border informal trade and remittances became a very important foreign currency supply for informal currency trade. So great has been this roadside currency trade that some important central business district sites have acquired for themselves the names of Bretton-Woods institutions such as the World Bank and the IMF. Excessive growth of nominal monetary balances not backed by production also occurred as speculative and arbitrage activities took the form of casino economy practices: foreign currency holders exchanged it at exorbitantly high parallel market exchange rate premium over the official exchange rate, and immediately used the real time gross settlement money balances to buy foreign currency at even higher premiums (Gukurume, 2010; Gukurume, 2015). This arbitragelike speculative behavior became known as the burning of money (Gono, 2008; Kararach \& Otieno, 2016) and up to this day this practice continues. In all likelihood, the burning of money drove parallel exchange rate premiums and parallel exchange rate premium drove money supply growth. The proceeds from parallel foreign currency dealing were also used to speculate in the real estate sector and on the Zimbabwe Stock Exchange (Gono, 2008). In the period 1998 to 2003 asset management companies, with no proper regulatory and supervisory framework, mushroomed everywhere and they became the engines of the casino economy (Fundira, 2007; Gono, 2008). 


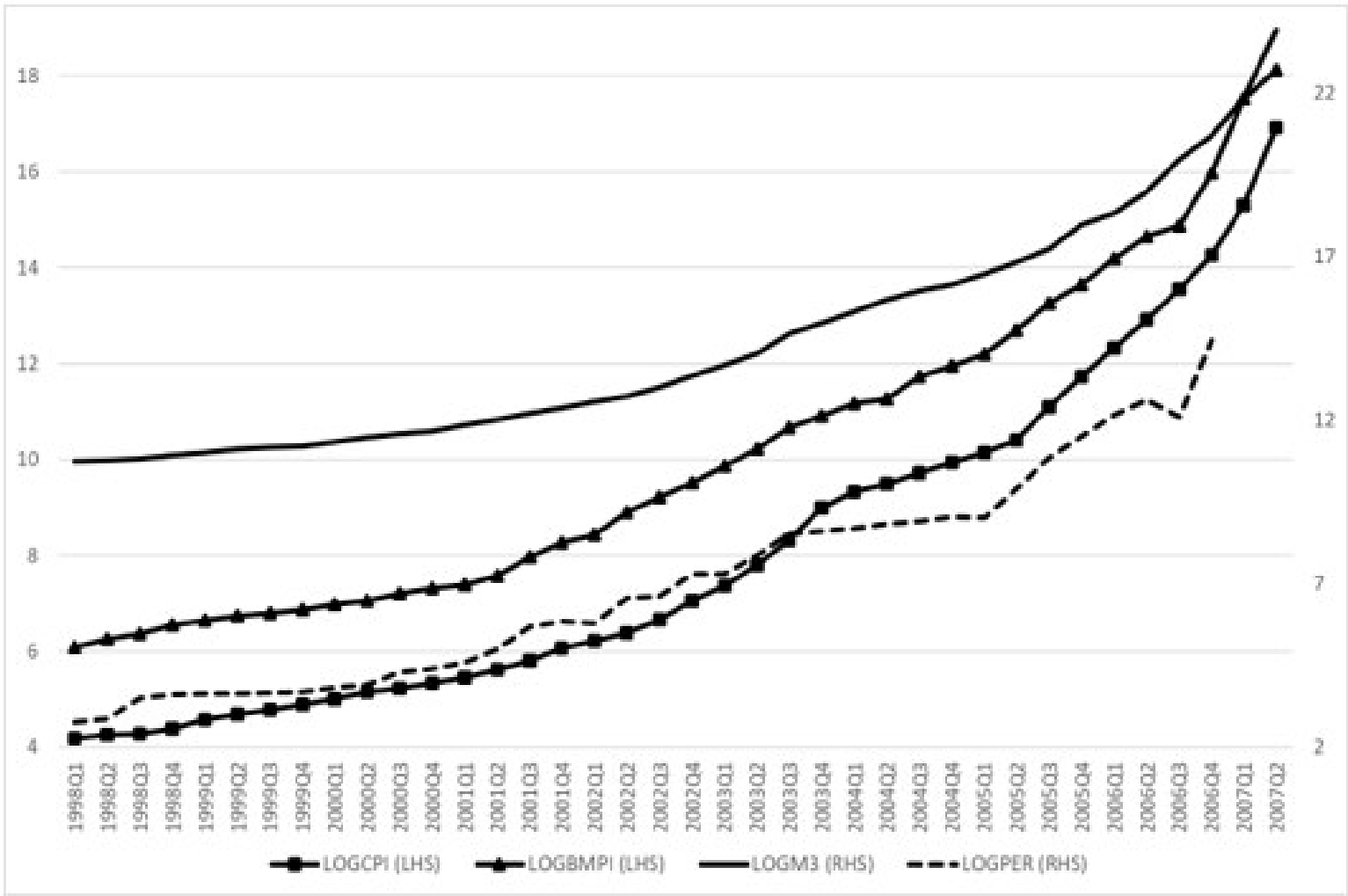

Figure 1: Evolution of consumer price index, building materials index, broad money and parallel exchange rate Source: Plotted using Reserve Bank of Zimbabwe and Zimbabwe Statistical Agency data

Figure 1 show a sustained increase in the building materials price index, consumer price index, parallel exchange rate and broad money. The central bank engaged in several quasi-fiscal activities between 2004 and 2008 which injected a lot of liquidity in the economy. Quasi-fiscal activities reached a high of $75 \%$ of GDP according to one estimate (Muñoz, 2007). These interventions included the trouble bank fund to rescue banks that were collapsing because of misgovernance, corruption and departure from the core business or simply greed (Fundira, 2007; Gono, 2008; Tembo, 2016), agricultural sector productivity enhancement facility, productive sector facility, farm mechanization program, basic commodities supply side intervention, winter crops facility, dam construction and irrigation rehabilitation fund. The repayment of these facilities was not always good and the facilities we also abused, beneficiaries channeling the funds into speculative trade. Thus much of the injected liquidity was not successfully mopped up. This means that the initial impulse for wild price dynamics always had its roots in good intentioned quasi-fiscal interventions (Figure 1).

In the period under study, Zimbabwe initially maintained a fixed exchange rate between 1998 and 2003. In 2004, a foreign exchange auction system was instituted to gradually introduce market forces in the allocation of foreign currency and so, to determine the exchange rate (Gono, 2008). The exchange rate management system was in fact a dual one because there was also a favourable exchange rate for the diaspora to attract remittances. Because of weak foreign currency generating capacity in the economy, it soon turned out to be a fixed exchange rate. Stringent export proceeds retention mechanisms were put in place to build up short term foreign currency reserves. Because of this repressive exchange rate management system, foreign currency earners ended up channeling their proceeds to the parallel market to earn better returns.

Government also instituted the National Incomes and Pricing Commission as part of a social contract to prevent indexation of wages and pricing to inflation, let alone to the parallel exchange rate (Gono, 2008). This initiative, while useful, did not manage to stop the galloping price level.

\subsection{Problem statement}

An untested claim of the then central bank governor, Gideon Gono, is that the real estate market alongside the stock exchange market and the parallel foreign currency market played a significant role in the evolution of inflation dynamics in Zimbabwe (Gono, 2008). Gono's thesis is that the phenomenon of shadow printing of money in the real estate - stock market - private banking sector complex has not been evaluated in existing scholarship in terms of its contribution to hyperinflation. The said shadow printing of money in the private banking in search of returns above the inflation rate resulted in money supply growing at a much faster rate than the price level itself. 
In one instance a whistle blower in one commercial bank informed the central bank that one of his/her bank's clients was bribing some bank official to issue fraudulent bank cheques against non-existent bank balances. Once the central bank was alerted, setting a trap in the clearing system, discovered "a staggering total of ZWD 60 hexillion ... in fraudulent cheques .... Which had become actual credit balances", a cheque scam of mega proportions (Gono 2008, 80). What we have here is an example of shadow printing of money: the ZWD 60 hexillion was 6 billion times larger than official currency in circulation and 55 times larger than total quasi-fiscal operations of the central bank that were valued at ZWD 1.1 hexillion. These fraudulent cheques were channeled into real estate and stock market trading, thus leading to stock prices for some counters gaining no less than 2 million percent in a single day. The Chief Executive Officer of the Zimbabwe Stock Exchange testified that there had been "lots of hot money", "rogue traders" and "fraudulent cheques" in the stock market (Gono 2008, 223). Similarly, discussing the bank cheque scam, also called 'burning money', the president of Bankers Association of Zimbabwe, currently governor of the central bank, pointed out that the cheque scam had "increase[d] credit creation when there is no asset that has been created and the results are very simple: it causes more inflation and indeed demand for cash" (Gono 2008, 224). This is the broader context within which hyperinflation became a literal inferno to the economy. The era 2002-2008 is a typical illustration of the problem of financialization of the economy (Palley, 2016).

Greed, corruption, and market indiscipline characterized by diversion of central bank productive sector concessionary facilities to speculation in the stock market, real estate and parallel foreign currency markets became daily experience. These markets were both unassailable inflation hedges for speculators and inflation drivers in the economy resulting in exponential growth in money supply. The central bank charged that "cash barons and dealers [were] in the habit of creating mini-Central Banks in their homes and offices in competition with our core function" (RBZ MPS, Oct 2007, 21). This in turn led to "excessive non-productive growth rates in money supply" (RBZ MPS, 2004, 39), which in turn drove inflation. Severe cash crises between 2002 and 2004 were directly linked to "corporate incest" (Gono, 2008: 124) whereby commercial banks left their core business and started speculating with depositors' funds in real estate assets as well as diverting depositors' funds to stock market and parallel market currency trading.

Existing scholarship on Reserve Bank of Zimbabwe monetary policy philosophy between 2003 and 2008 is generally silent about the market indiscipline that was rampant at the time a couple of years prior to that period. While acknowledging market indiscipline in the 2003-2008 period, they often do so dismissively and blaming the central bank for engineering it e.g. (Mpofu \& Nyamadzawo, 2016; Shumbambiri, 2016). The economy was undergoing a colossal speculative bubble in the stock market, banking sector and the real estate market, significantly fueled by parallel foreign currency trade. The bubble began since the late 1990s. There was a casino economy ethic pervading the economy. Large volumes of unproductive cash were being churned out into the economy through speculative activities. The excessive growth of nominal money supply was driven by activities that bordered (or indeed were manifestations) money laundering (Fundira, 2007).

The paper contributes to evolving scholarship on Zimbabwean hyperinflation in two ways. First, the paper looks at the parallel exchange rate-inflation-money supply-real estate price nexus. Existing scholarship has explored separately the exchange rate-inflation nexus, parallel exchange rate-inflation nexus and money supplyinflation nexus. By not completing the chain of the dynamic interactions, the findings might be painting an incomplete picture. Second, despite data challenges, the paper incorporates the real estate sector into the analysis, which makes it the first paper to directly test Gono's thesis. Sadly, Zimbabwe Stock Exchange at a quarterly frequency was not found: had it been, the circle would have been perfectly completed. Third, some of the papers have questionable empirical procedures, which make their results suspect. To give a few examples, Shumbambiri (2016) finds the money neutrality hypothesis to have held in Zimbabwe between 2000 and 2008 using residuals from a spurious regression to test for cointegration; Madesha, Chidoko, \& Zivanomoyo (2013), while testing the link between official exchange rate and inflation, treat one of the variables as stationary after first difference when it is not. In this paper, we adopt an Autoregressive Distributed Lag modelling framework and performs cointegration analysis within that framework. This methodology is superior to single equation cointegration methods some of the papers use.

\subsection{Significance of the study}

Zimbabwe has relapsed into hyperinflation in a decade after the first hyperinflation episode of 2003-2008 despite ample lessons from her own economic history. The same markets that Gono blamed for irrational exuberance seem to remain dominant in the evolution of inflationary dynamics in Zimbabwe. Since scholarship has not empirically tested these claims the study fills a significant void in this regard. Filling this void is not only valid from an economic history point of view but also for informing policy in Zimbabwe.

\section{Empirical discourses}

Muñoz (2006), perhaps the first to study in detail Zimbabwean hyperinflation, explored the unusual divergence 
between the evolution of real money balances and inflation, the latter showing a rapid decline while the former was increasing. 'Conventional wisdom', they argue, suggests a U-shape in the evolution of real money balances declining first and then rising as stabilization progresses. They find it puzzling that inflation led rather than lagged changes in money supply aggregates. Muñoz's (2006) findings point to suppressed inflation and measurement errors in the consumer price index, especially given outdated weights, which resulted in unusually high real money balances.

Several concerns with Muñoz's (2006) paper deserve to be mentioned. Firstly, the analysis assumed that there was monetary equilibrium, $\mathrm{Ms}=\mathrm{Md}$, in the 1998-2004 period. Yet, there was disequilibrium because there were widespread cash shortages since 2002 (Ms < Md), heightening in 2004, when the RBZ read the riot act to banks that had tied depositors' moneys in illiquid real estate assets, stock market speculation and illegal foreign exchange dealings (Gono, 2008). Secondly, the problem of reverse causality is all the more inescapable in their analysis, especially between monetary aggregates and the parallel exchange rate as well as between monetary aggregates and real GPD, given that in 2004-2005 capacity utilization improved in some sectors following quasi-fiscal interventions. Thirdly, nowhere in the paper do they acknowledge the rampant problem of money laundering that was evolving in the quadrilateral relationship between the stock market, banking sector, real estate, and parallel foreign exchange market (Fundira, 2007; Gono, 2008). The rapid correction that followed several institutional reforms including banking sector corporate governance reforms and a return to core activities by the financial sector was a structural shock in the relationship between real money balances and inflation. Monetary policy had to be a double-edged sword: injecting the much-needed liquidity to the real sector (hence growth in real money balances), while correcting market indiscipline (thwarting speculative impulses on inflation, a major driver of inflation then). Thus, divergence of real money demand and inflation was inevitable.

McIndoe-Calder (2018) also constructs a new price index based on the parallel exchange rate. Like Muñoz (2006), McIndoe-Calder (2018) finds growth in money supply to be the major driver of inflation. They dispute the narrative by the central bank that speculative price setting behavior played a key role in the evolution of the hyperinflationary episode in Zimbabwe. They find seigniorage revenue to have grown substantially in the post 2000 period. Makochekanwa (2007a; 2007b) similarly finds money supply growth, parallel market exchange rate and inflation inertia to be major causes of hyperinflation. Others have invariably found excessive money supply growth to be the cause of hyperinflation (Hanke 2008; Hanke and Kwok 2009).

Madesha et al. (2013) confirm the bi-directional causal relationship between official exchange rate and inflation in Zimbabwe, which must be even much stronger between parallel exchange rate and inflation. However, the results of their study are suspect, because they misinterpreted their unit root test results for the inflation variable. They concluded it was I(1) when, in fact, it was not stationary in first difference. The Johansen cointegrating methodology that followed, and the Granger causality results, therefore, were spurious at best. Nevertheless, it is established theoretically that there is always an "inflation-depreciation spiral" (Kararach \& Otieno, 2016: 250), regardless of whether it is depreciation of the official or the parallel exchange rate. In fact, Kararach \& Otieno (2016) found that changes in money supply granger-caused changes in the consumer price index which in turn granger-caused changes in the official nominal exchange rate. They also found that changes in the parallel nominal rate granger-caused changes in the official nominal exchange rate. Finding one cointegrating vector between nominal official exchange rate, relative money supply (Zim to US) and relative output (Zimbabwe to US), Kararach \& Otieno (2016) estimated a VECM and found evidence of the overshooting phenomenon in the manner in which the exchange rate adjusted to its long run equilibrium, suggesting an unstable cointegrating relationship.

Shumbambiri (2016) tests the RBZ maintained conviction that monetary policy was not neutral to growth, using quarterly data for the period 2000 to 2008. Using a single equation cointegration test they established that money supply and economic growth were not cointegrated on the one hand, and money supply and inflation on the other were cointegrated. This armed them to reject the non-neutrality of money that the RBZ maintained in the study period because no cointegration was established for economic growth and money supply. Further they find existence of bi-directional causality between money supply and inflation, which though defying the Quantity Theory of Money, they still use it to make the QTM prescription that to stop inflation the RBZ must stop expanding money supply. The QTM assumes unidirectional causality from money supply to inflation. However, their finding of neutrality of money is a red herring because the residuals to which they applied the single equation cointegration approach were generated from a spurious regression in which the DW statistic was a third of the $\mathrm{R}^{2}$.

Ellyne \& Daly (2013) explore the line that Zimbabwe's deplorable monetary policy failure is explained by the Impossible Trinity Hypothesis. The central bank was trying to set both monetary policy and the exchange rate policy while allowing for capital mobility. They find the parallel exchange rate-inflation spiral to have been a dominant phenomenon in 1998-2008.

Kairiza (2009) acknowledges supply-side shocks embodied in the fast track land reform, but goes on to single out political rent-seeking process that involved the ruling party 'appeasing' its angry support base with significant political rent transfers. These led to excessive growth in money supply. In light of this, Kairiza $(2009,1)$ disputes the genuineness of the expansionary monetary policy and charges that 
The liquidity expansion by the central bank to prop the ruling party embodied in the quasi-fiscal activities veiled as expansionary Keynesian economics played a major role in firmly setting the stage for hyperinflation in the latter stages of the saga (emphasis added).

Since, in Kairiza's (2009) assessment, the policy target was neither full employment nor low and stable inflation, the policy was a 'pseudo-Keynesian' policy. Other scholars have pointed out that there has been, since political independence in 1980, a pattern of anti-developmental patrimonialism in Zimbabwe, with extensive ruling party networks of rent extraction from the financial, trade and productive sectors of the economy (Dawson \& Kelsall, 2012). At the heart of hyperinflation were political and economic misgovernance, the battle for political survival. In this context, seigniorage revenue from the central bank was used to ring-fence political power, a point Ndlovu-Gatsheni (2015) emphasizes as the pillaging of the central bank in the era of Mugabeism. Part of the complex of factors that undermined monetary policy includes rent seeking activities associated with allocation of foreign currency, especially to state owned enterprises that invariably had become militarized and impossible for the RBZ to reprimand for non-delivery of the services for which they had been given preferential foreign currency allocation. It is reported that by 2008, at least 52 state-owned enterprises were governed by retired senior military officials who, in a zealot-like allegiance, were invariably members of the ruling party (Rupiya, 2011). The basis of the preferential access to foreign currency was because many of these local government authorities and stateowned enterprises were crucial supply-side sources of inflationary shocks, especially those supplying fuel, electricity and cargo transport services (Gono, 2008).

In short, the diagnoses, some of which I have reviewed here, identify the unconventional monetary policy stance of the central bank as the underlying cause of the Zimbabwean economic crisis, especially hyperinflation. Such unconventionality, they say, was not a genuine Keynesian monetary policy thrust, but a disguised looting strategy.

\section{Methods and data}

\subsection{Empirical model}

Based on the articulation of the empiricised, theoretical or surmised relationships between inflation, real estate prices, parallel foreign exchange and money supply, the paper adopts a linear functional relationship:

$\log C P I_{t}=f\left(\log B M P I_{t}, \log M_{3 t}, \log P E R_{t}\right)$

$\operatorname{LogCPI}_{t}$ is the natural logarithm of the consumer price index; $\log B \mathrm{MPI}_{t}$ is the natural $\log$ of the building materials price index (a proxy for real estate sector dynamics); $\log \mathrm{M} 3 \mathrm{t}$ is the natural logarithm of broad money supply; and $\log \mathrm{PER}_{\mathrm{t}}$ is the natural logarithm of the parallel exchange rate. $t$ is a time index. While the building materials price index is not the best of candidates, it is sufficient to demonstrate the role of real estate price dynamics on inflation. The weakness is that it does not fully capture the speculative component of the real estate market since it focuses on real estate input prices rather than final output prices. The latter would be more representative of the dynamics. Since banks and other players engaged in real estate investments as inflation hedges. Some moneys were tied in bricks, cement and other building materials (Gono, 2008). This means that the building materials price index is not entirely a misplaced proxy for real estate market dynamics.

While several techniques for testing for the existence of long run relationships exist, the autoregressive distributed lag (ARDL) approach is generally regarded is the most efficient and reliable relative to the rest (Pesaran, 2015). This approach is well suited to large and small samples alike: the order of integration and sample size are not pressing concerns. As a precautionary measure individual series unit root tests were carried out and are reported in Table 1. Variables were of mixed orders of integration. Given the small sample size, the ARDL test is most suitable. A bounds test for cointegration was employed. The test model is stated as follows:

$\Delta \log C P I_{t}=\beta_{0}+\sum_{i=1}^{4} \beta_{1} \Delta \log C P I_{t-i}+\sum_{i=1}^{4} \beta_{2} \Delta \log B M P I_{t-i}+\sum_{i=1}^{1} \beta_{3} \Delta \log M_{3 t-i}+\sum_{i=1}^{2} \beta_{4} \Delta \log P E R_{t-i}+$ $\gamma_{1} \log C P I_{t-1}+\gamma_{2} \log B M P I_{t-1}+\gamma_{3} \log M_{3 t-1}+\gamma_{4} \log P E R_{t-1}+\alpha_{i} d u m m y_{t}+\mu_{t}(2)$

In equation $2, \mu_{t}$ is a stochastic error term; $\Delta$ is a difference operator. The summation upper limits are optimal lag lengths determined by information criteria - in this case, the Akaike Information Criterion, giving $\Delta \log C I_{t}(4,4,1,2)$. A dummy variable taking the value of one (1) for 2004Q1-2007Q2 and zero otherwise was introduced to differentiate the Gideon Gono governorship era from the Leonard Tsumba governorship era. In the interest of assessing the potential of reverse causality, equation 2 was repeated with each explanatory variable being treated as a dependent variable. The optimal lag lengths for the other three alternative specifications were: ARDL for $\Delta \log B M P I_{t}(2,1,4,3)$; for $\Delta \log M_{3 t}(4,4,1,1)$ and $\Delta \log P E R_{t}(3,0,1,4)$. To test for existence of a long run relationship between the dependent and explanatory variables, the null hypothesis tested is that $\gamma_{1}=\gamma_{2}=$ $\gamma_{3}=\gamma_{4}=0$ against the alternative that $\gamma_{1} \neq \gamma_{2} \neq \gamma_{3} \neq \gamma_{4} \neq 0$. The null hypothesis claims no existence of a long run relationship, but the alternative does. The bounds test fails to reject the null hypothesis if both the test statistic for the $\mathrm{F}$ and the $\mathrm{t}$ are less than lower critical bounds. The null hypothesis is rejected if the $\mathrm{F}$ and the $\mathrm{t}$ statistics exceed the upper critical bound.

Failure to reject the null hypothesis implies that only the short-run model is estimated. If the null hypothesis is rejected, then a long run relationship exists. An error correction model is then modelled as follows: 
$\Delta \log C P I_{t}=\beta_{0}+\sum_{i=1}^{2} \vartheta_{1} \Delta \log C P I_{t-i}+\sum_{i=1}^{1} \vartheta_{2} \Delta \log B M P I_{t-i}+\sum_{i=1}^{4} \vartheta_{3} \Delta \log M_{3 t-i}+\sum_{i=1}^{3} \vartheta_{4} \Delta \log P E R_{t-i}+$ $\alpha_{i}$ dummy $_{t}+\theta_{i} E C M_{t-1}+\varepsilon_{t}$

The parameter of interest in equation 3 is $\theta_{i}$ is the speed of adjustment to the long run. If the cointegration relationship is to be stable, convergent and non-spurious, this parameter must be negative and significant. Generally, $\theta_{i} \in(-1,0)$ but if it is less than -1 literature tends to interpret that as an overcorrection of the short run divergence from the long run.

\subsection{Data and variables}

Data for this empirical paper was obtained from the Reserve Bank of Zimbabwe's pre-multicurrency regime economic statistics. The building materials price index was obtained from the Zimbabwe Statistical Agency. Data for the latter half of 2007 and 2008 was difficult to find for all variables. Were variables had different base years, conversion factors supplied by the Zimbabwe Statistical Agency were used to make the base year uniform and 2008 was used as a base year. Data for the Zimbabwe Stock Exchange Index was not complete and not quarterly. So it was not included in the analysis. The data was measured at a quarterly frequency between 1998 and 2007 : 1998Q1-2007Q2.

\section{Statistical tests and findings}

4.1 Unit root test and Bounds test

Table 1: Unit root tests

\begin{tabular}{|l|l|l|l|l|l|l|}
\hline Variable & \multicolumn{4}{|l|}{ Augmented Dickey-Fuller } & \multicolumn{2}{l|}{ Phillips-Peron } \\
\hline & Levels & $\begin{array}{l}\text { First } \\
\text { difference }\end{array}$ & $\begin{array}{l}\text { Second } \\
\text { difference }\end{array}$ & Levels & $\begin{array}{l}\text { First } \\
\text { difference }\end{array}$ & $\begin{array}{l}\text { Second } \\
\text { difference }\end{array}$ \\
\hline $\begin{array}{l}\text { Log Consumer Price } \\
\text { Index }\end{array}$ & $2.362(3)$ & $1.726(3)$ & $-3.335^{* *(3)}$ & 6.830 & 2.479 & $-3.237^{* *}$ \\
\hline $\begin{array}{l}\text { Log Building } \\
\text { Materials Price Index }\end{array}$ & $4.222(3)$ & $0.721(3)$ & $-8.519^{* * *(3)}$ & 5.634 & $-2.939^{*}$ & $-8.292^{* * *}$ \\
\hline $\begin{array}{l}\text { Log Broad Money } \\
\text { Supply (M) }\end{array}$ & $2.960(2)$ & $3.242(2)$ & $-0.862(2)$ & 3.560 & 1.714 & $-5.230^{* * *}$ \\
\hline $\begin{array}{l}\text { Log Parallel Exchange } \\
\text { Rate }\end{array}$ & $2.438(2)$ & $-5.376^{* * *}(2)$ & & -3.188 & $-5.753^{* * *}$ & \\
\hline
\end{tabular}

$* * *$ means $\mathrm{p}<0.01, * *$ means $\mathrm{p}<0.05, *$ means $\mathrm{p}<0.1$; figures in brackets are optimal lag lengths selected by AIC. Log M3 had a significant trend component; the rest did not have significant trend components.

Unit root tests presented in Table 1 show that variables are not integrated of the same order. The test equation included intercept (trend was insignificant) and the Akaike Information criteria suggested 3 lags for the ADF test equation for the log of building materials price index and the log consumer price index. For log of broad money (M3) and the log of parallel exchange rate, the AIC suggested 2 lags for the ADF test. Only the log of parallel exchange rate was integrated of order one at the $1 \%$ level of significance. The log of building materials price index and the log of consumer price index were integrated of order of two going by the ADF test. Log of M3 was not stationary even after second difference. We, however, retained it in the analysis given its centrality in the debates about hyperinflation dynamics in Zimbabwe. Using the Phillips-Peron test, the log of CPI, the log of BMPI and the log of M3 were integrated of order two, but the log of the parallel exchange rate was integrated of order one. Table 2: Bounds test for cointegration

\begin{tabular}{|l|l|l|l|l|}
\hline Model & $\mathrm{F}$ & Level of significance & Lower bound & Upper bound \\
\hline $\log$ BMPI $(2,1,4,3)$ & $11.975^{* * *}$ & $10 \%$ & 2.72 & 3.77 \\
& & $5 \%$ & 3.23 & 4.35 \\
& & $1 \%$ & 4.29 & 5.61 \\
\hline $\log$ CPI $(4,4,1,2)$ & $14.748^{* * *}$ & & & \\
\hline $\log M_{3}(4,4,1,1)$ & $4.888^{* *}$ & & & \\
\hline $\operatorname{logPER}(3,0,1,4)$ & $5.343^{* *}$ & & & \\
\hline
\end{tabular}

$* * *$ means $\mathrm{p}<0.01, * *$ means $\mathrm{p}<0.05, *$ means $\mathrm{p}<0.1$

The bounds test established four long run relationships: first, $\log \mathrm{BMPI}=\mathrm{f}(\log \mathrm{CPI}, \log \mathrm{M} 3, \log \mathrm{PER})$; second, $\log \mathrm{PER}=\mathrm{f}(\log \mathrm{CPI}, \log \mathrm{M} 3, \log \mathrm{BMPI})$; and third, $\log \mathrm{CPI}=\mathrm{f}(\log \mathrm{M} 3, \log \mathrm{BMPI}, \log \mathrm{PER})$ and fourth $\log 33=$ $\mathrm{f}(\log \mathrm{CPI}, \log \mathrm{BMPI}, \log \mathrm{PER})$. However, while a long run relationship in the $\log \mathrm{M} 3=\mathrm{f}(\log \mathrm{CPI}, \log \mathrm{BMPI}, \log P E R)$ existed, the ECM did not satisfy the negativity constraint on the speed of adjustment measure. Thus three error correction models were estimated and one short run equation, which we have not reported in the paper. 


\subsection{Empirical Results}

Table 3: Long run and short run regression results

\begin{tabular}{|c|c|c|c|c|}
\hline & $\Delta \log C P I_{t}(4,4,1,2)$ & $\Delta \log B M P I_{t}(2,1,4,3)$ & $\Delta \log M_{3 t}(4,4,1,1)$ & $\Delta \log P E R_{t}(3,0,1,4)$ \\
\hline Intercept & $\begin{array}{l}-6.409 * * * \\
(0.762)\end{array}$ & $\begin{array}{l}-1.628 * * * \\
(0.226)\end{array}$ & $\begin{array}{l}-0.617 * * * \\
(0.116)\end{array}$ & $\begin{array}{l}-1.171 * * * \\
(0.246)\end{array}$ \\
\hline$\Delta \log B M P I_{t}$ & $\begin{array}{l}-0.232 * \\
(0.125)\end{array}$ & $\begin{array}{l}-0.193 \\
(0.131)\end{array}$ & $\begin{array}{l}0.287 * * \\
(0.128)\end{array}$ & $\begin{array}{l}3.169 * * * \\
(0.390)\end{array}$ \\
\hline$\Delta \log B M P I_{t-1}$ & $\begin{array}{l}-0.100 \\
(0.111)\end{array}$ & & & \\
\hline$\Delta \log B M P I_{t-2}$ & $\begin{array}{l}-0.086 \\
(0.113) \\
\end{array}$ & & & \\
\hline$\Delta \log B M P I_{t-3}$ & $\begin{array}{l}-0.385 * * * \\
(0.105)\end{array}$ & & & \\
\hline$\Delta \log C P I_{t}$ & & $\begin{array}{l}-0.059 \\
(0.139)\end{array}$ & $\begin{array}{l}0.264 * * \\
(0.106)\end{array}$ & \\
\hline$\Delta \log C P I_{t-1}$ & $\begin{array}{l}0.636^{* * *} \\
(0.112)\end{array}$ & & $\begin{array}{l}1.017 * * * \\
(0.148)\end{array}$ & \\
\hline$\Delta \log C P I_{t-2}$ & $\begin{array}{l}0.217^{*} \\
(0.114)\end{array}$ & & $\begin{array}{l}-0.386^{* *} \\
(0.148)\end{array}$ & \\
\hline$\Delta \log C P I_{t-3}$ & $\begin{array}{l}0.457 * * * \\
(0.112)\end{array}$ & & $\begin{array}{l}0.443 * * * \\
(0.134)\end{array}$ & \\
\hline$\Delta \log M_{3 t}$ & $\begin{array}{l}0.093 \\
(0.080)\end{array}$ & $\begin{array}{l}0.137 \\
(0.087)\end{array}$ & & $\begin{array}{l}-0.185 \\
(0.300)\end{array}$ \\
\hline$\Delta \log M_{3 t-1}$ & & $\begin{array}{l}-0.056 \\
(0.125)\end{array}$ & $\begin{array}{l}-0.752 * * * \\
(0.154)\end{array}$ & $\begin{array}{l}0.188 \\
(0.325)\end{array}$ \\
\hline$\Delta \log M_{3 t-2}$ & & $\begin{array}{l}-0.024 \\
(0.095)\end{array}$ & $\begin{array}{l}-0.724 * * * \\
(0.197)\end{array}$ & $\begin{array}{l}0.717 * \\
(0.385)\end{array}$ \\
\hline$\Delta \log M_{3 t-3}$ & & $\begin{array}{l}-0.598 * * * \\
(0.139)\end{array}$ & $\begin{array}{l}0.652 * * * \\
(0.164)\end{array}$ & $\begin{array}{l}1.816^{* *} \\
(0.734) \\
\end{array}$ \\
\hline$\Delta \log P E R_{t}$ & $\begin{array}{l}0.091 * \\
(0.044)\end{array}$ & $\begin{array}{l}0.224 * * * \\
(0.029)\end{array}$ & $\begin{array}{l}0.025 \\
(0.042)\end{array}$ & \\
\hline$\Delta \log P E R_{t-1}$ & $\begin{array}{l}0.152 * * * \\
(0.042)\end{array}$ & $\begin{array}{l}-0.130 * * \\
(0.050)\end{array}$ & & $\begin{array}{l}0.421 * * \\
(0.183)\end{array}$ \\
\hline$\Delta \log P E R_{t-2}$ & & $\begin{array}{l}-0.160 * * * \\
(0.035)\end{array}$ & & $\begin{array}{l}0.530 * * * \\
(0.159)\end{array}$ \\
\hline D04Q1-07Q2 & $\begin{array}{l}-0.077 * * * \\
(0.022)\end{array}$ & $\begin{array}{l}0.023 \\
(0.027)\end{array}$ & $\begin{array}{l}-0.309^{* * *} \\
(0.068)\end{array}$ & $\begin{array}{l}-0.061 \\
(0.103)\end{array}$ \\
\hline$E C M_{t-1}$ & $\begin{array}{l}-1.059 * * * \\
(0.126)\end{array}$ & $\begin{array}{l}-0.295 * * * \\
(0.039)\end{array}$ & $\begin{array}{l}0.031 * * * \\
(0.006)\end{array}$ & $\begin{array}{l}-1.279 * * * \\
(0.257)\end{array}$ \\
\hline $\begin{array}{l}\mathrm{R}^{2}= \\
\mathrm{F}= \\
\text { Jarque-Bera = } \\
\text { Breusch- } \\
\text { Godfrey LM = }\end{array}$ & $\begin{array}{l}0.976 \\
65.36(\mathrm{p}<0.01) \\
2.506(\mathrm{p}=0.286) \\
3.301(\mathrm{p}=0.069)\end{array}$ & $\begin{array}{l}0.973 \\
64.5(\mathrm{p}<0.01) \\
0.26(\mathrm{p}=0.878) \\
4.174(\mathrm{p}=0.124)\end{array}$ & $\begin{array}{l}0.966 \\
51.89(\mathrm{p}<0.01) \\
1.971(\mathrm{p}=0.373) \\
2.367(\mathrm{p}=0.124)\end{array}$ & $\begin{array}{l}0.919 \\
27.86(p<0.01) \\
2.004(p=0.367) \\
3.389(p=0.184)\end{array}$ \\
\hline
\end{tabular}

The purpose of this study was to test the claim by the then governor of the central bank, Gideon Gono, who presided over the worst hyperinflation that inflation was driven by speculative activity in the real estate market and parallel foreign exchange market. The prism would have been complete had data for the stock exchange been found. Three error correction mechanisms with desirable properties for the error correction term - negative and statistically significant - were found (Table 3 ).

In the case of the regression for $\Delta \log C P I_{t}$ (Table 3) shocks in the building materials price index, parallel market exchange rate and money supply would cause inflation to diverge from its equilibrium path. The results suggest that a $1.06 \%$ of the disparity between the short run and the long run values for logCPI in the previous quarter would be corrected in current quarter. This means that there is an overcorrection of the equilibrium error by $0.06 \%$. The speed of adjustment is almost unity which suggests instantaneous inflation adjustment to long run equilibrium, with a little noise that causes overcorrection. We observe a very strong element of inertia in the evolution of inflation dynamics. The cumulative effect of inflation for the previous three quarters, on average, is approximately $1.3 \%$ increase in current price level dynamics, ceteris paribus. News about an increase in inflation, takes longer to die out in the economy: prolonged lagged effects. Perhaps, this suggests a presence of adverse 
adaptive inflation expectations in the economy. All the coefficients of the parallel exchange rate are positive suggesting that this economic price was a significant source of inflationary pressure. Unfortunately, all the short run coefficients of the building material price index are negative. One would have expected these coefficients to be positive. The dummy variable shows that the inflation rate was $7.4 \%$ lower than it was in the pre Gono era in the study period. The model was adequate. It is structurally stable according to the CUSUM and CUSUMSQ tests (see Figure 2). The residuals are normally distributed. There is some evidence of serial correlation at the $10 \%$ level of significance.

In the case of the regression for $\Delta \log B M P I_{t}$ (Table 3), about $29.5 \%$ of the wedge between the short run and long run values of $\operatorname{logBMPI}$ in the previous quarter, following a shock in the other variables, is corrected in the current quarter. The effect of parallel exchange rate on the BMPI is mixed. The current quarter parallel exchange rate has a positive effect on the building materials price index, but the effects of the parallel exchange rate in the previous two quarters are negative. Perhaps, this can be explained by the role foreign exchange trading is an alternative way of storing and growing value just as speculative investing in the real estate is. A speculator holds a portfolio of assets among which are foreign exchange and real estate assets. Perhaps, this suggests that the more resources were poured into foreign currency trading, the less was available for real estate investment. This then dampens demand for building materials. It is worth noting that the parallel exchange rate is a very influential variable in the short run, judging by the absolute sizes of its coefficients. The model was adequate. It is structurally stable according to the CUSUM and CUSUMSQ tests (see Figure 3 ). The residuals are normally distributed.

In the case of the regression for $\triangle \log P E R_{t}$ (Table 3), the parallel exchange rate has a significant inertia mechanism governing its evolution over time. This means that the rate is path dependent in its evolutionary dynamics and is generally sticky downwards. In the short run, however, the building materials index has the greatest effect on the parallel exchange rate: a 1\% increase in the BMPI leads to just over 3\% depreciation in the parallel exchange rate. Gono's argument of a casino inferno brewing between the real estate and parallel exchange rate seems confirmed here. The transmission mechanism as we perceive it was that once real estate prices started increasing, given real estate investments were used as inflation hedges, there was a greater likelihood that demand for foreign currency to acquire properties might end up pushing up the parallel exchange rate. This means that people dump Zimbabwean dollars into the market and mop foreign currency. This leads to the depreciation of the Zimbabwean dollar. Similarly, the short run coefficients for broad money supply show that expansionary monetary policy induced significant parallel exchange rate depreciation. For example, the cumulative effect of expansionary monetary stances in the previous second and third quarters would lead to a $2.5 \%$ depreciation of the parallel exchange rate, all else being equal. This suggests that the parallel exchange rate was quite responsive to growth in money supply. The model is structurally stable according to the CUSUM and CUSUMSQ tests (see Figure 5). The residuals are normally distributed.

In the case of the regression for $\Delta \log M_{3 t}$ (Table 3), a short run relationship (not reported here was estimated). Setting aside the speed of adjustment multiplier which is very small and positive, the rest of the coefficients in the regression make economic sense. Interestingly, coefficients of lagged differenced broad money are mostly negative. This suggests that a constant effort to mop excess liquidity from the market. Since inflation remained number one enemy of the central bank, but several quasi-fiscal interventions were carried out, it makes sense that efforts to mop up liquidity would follow an initial surge in liquidity through open market operations. In addition several quasi-fiscal interventions repayment dates staggered which means there was a semi-automatic liquidity correction mechanism as repayment dates approached. Thus, the cumulative effect for three previous quarters was roughly a $0.8 \%$ decrease in money supply. We note that money supply was relatively elastic to increases in inflation. For example the net effect of the inflation changes in the previous three quarters would lead to a $1.07 \%$ increase in nominal broad money. The rate of money growth was about $26.6 \%$ lower in the Gono era than it was in the Tsumba era, other things being equal. The model has good diagnostics. Coefficients are stable and the model does not suffer serial correlation. Similarly, the residuals of the model do not violate the normality assumption.

In terms of Granger causality tests (Table 4), our findings suggest that there is bidirectional causality between $\log$ BMPI and $\log$ M3. This bidirectional causality confirms Gono's argument that speculation in the real estate market and other inflation-hedging markets induced monetary growth through the credit creation process as well as money laundering activities of the form of shadow printing of money such as the cheque scam (Fundira, 2007; Gono, 2008). A bidirectional causality was also found between the CPI and M3, which others have also found (Shumbambiri, 2016). This finding is closest to confirming the claims of the trilateral relationship amongst these variables. Unidirectional causality from parallel exchange rate to inflation was observed. Also a unidirectional causal effect from building materials price index to money supply growth. This result is also closer to confirming the governor's hunch, although it does not tell us if the effect is positive or negative. We also found unidirectional causality from money supply growth to the parallel exchange rate. This result confirms anecdotes such as 'the Reserve was printing money to source foreign currency on the parallel market'. The Granger causality results are broadly consistent with the ARDL results. 


\subsection{Coefficient diagnostics}

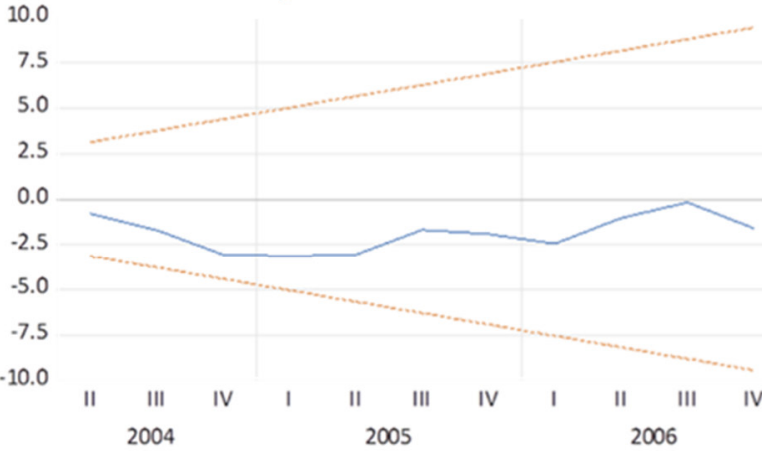

— CUSUM ...... $5 \%$ Significance

Figure 2: CUSUM test for $\Delta \log C P I_{t}$

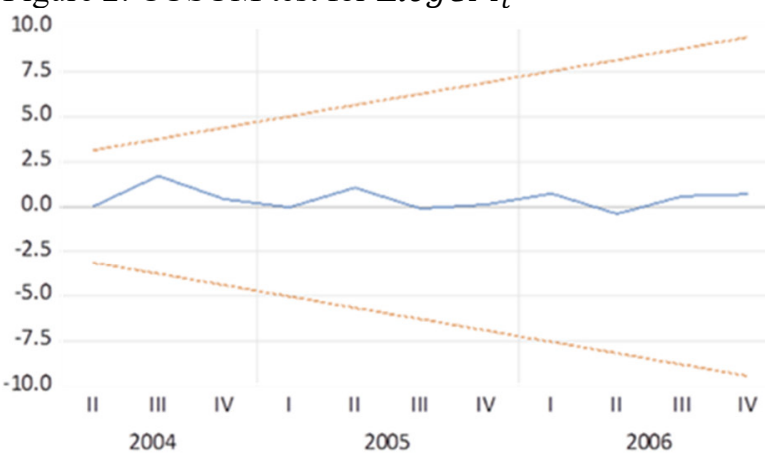

— CUSUM ...... $5 \%$ Significance

Figure 3: CUSUM test for $\triangle \log B M P I_{t}$

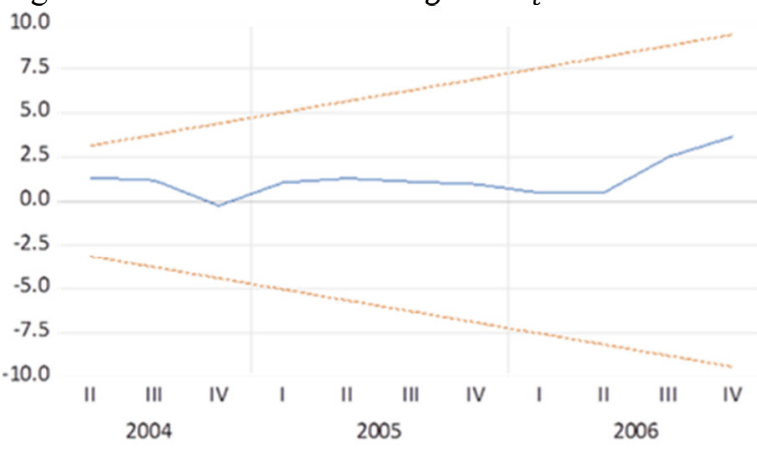

$$
\text { — CUSUM ...... } 5 \% \text { Significance }
$$

Figure 4: CUSUM test for $\Delta \log M_{3 t}$

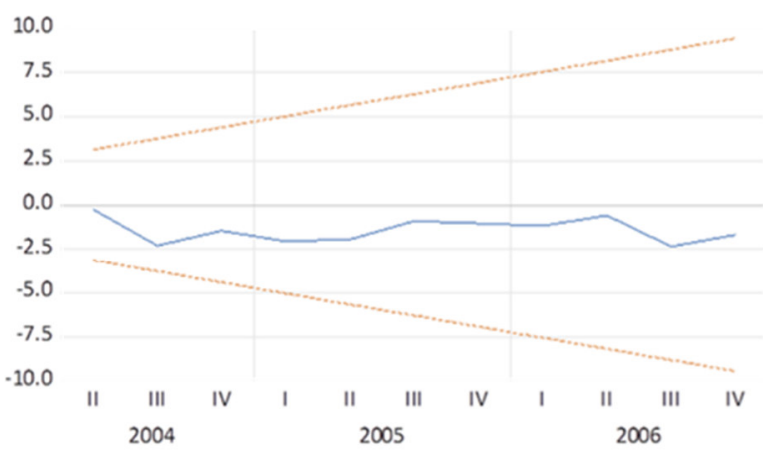

— CUSUM ...... $5 \%$ Significance

Figure 5: CUSUM test for $\triangle \log P E R_{t}$

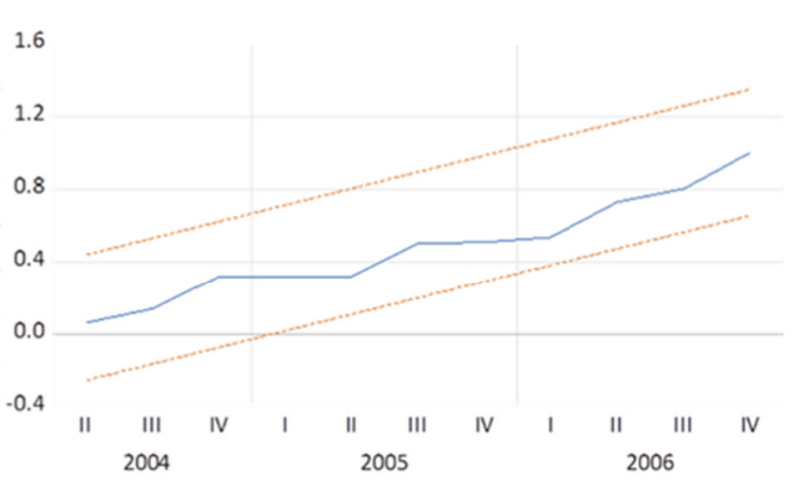

— CusUM of Squares ...... $5 \%$ Significance

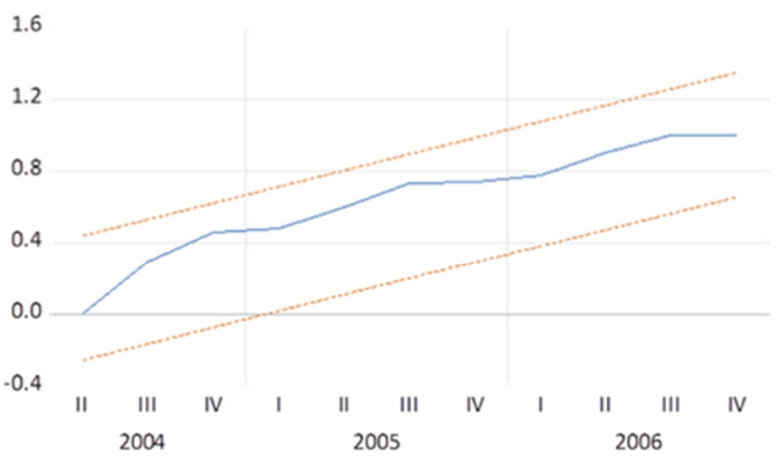

_ CUSUM of Squares ...... $5 \%$ Significance

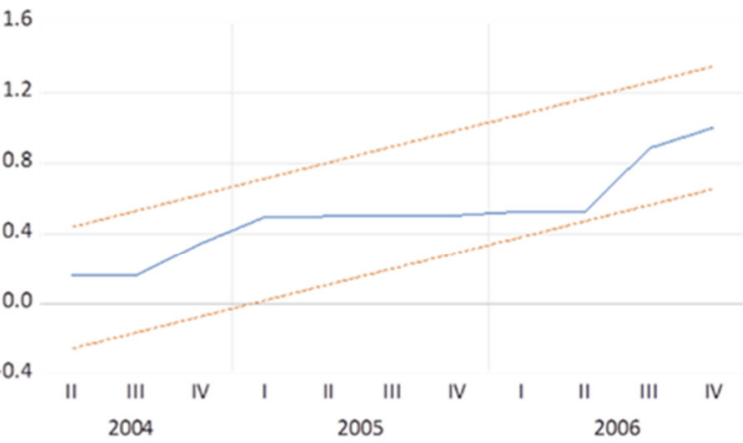

— CUSUM of Squares ...... $5 \%$ Significance

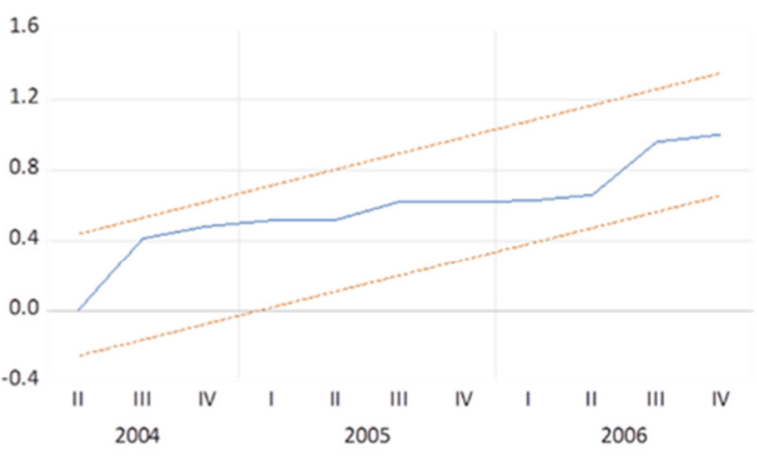

_ CUSUM of Squares ...... $5 \%$ Significance 
Table 4: Granger Causality results at 2 lags

\begin{tabular}{|c|c|c|c|}
\hline Null hypothesis & Observations & F-Statistics & P-value \\
\hline $\begin{array}{l}\text { logBMPI does not granger cause } \log C P I \\
\text { logCPI does not granger cause } \operatorname{logBMPI}\end{array}$ & 36 & $\begin{array}{l}19.392 \\
1.164 \\
\end{array}$ & $\begin{array}{l}0.000 \\
0.325 \\
\end{array}$ \\
\hline $\begin{array}{l}\operatorname{LogM}_{3} \text { does not granger cause } \log C P I \\
\log C P I \text { does not granger cause } \log M 3\end{array}$ & 36 & $\begin{array}{l}24.552 \\
9.852\end{array}$ & $\begin{array}{l}0.000 \\
0.001\end{array}$ \\
\hline $\begin{array}{l}\text { logPER does not granger cause logCPI } \\
\text { logCPI does not granger cause logPER }\end{array}$ & 34 & $\begin{array}{l}3.842 \\
0.795\end{array}$ & $\begin{array}{l}0.033 \\
0.461\end{array}$ \\
\hline $\begin{array}{l}\log M_{3} \text { does not granger cause } \log B M P I \\
\log B M P I \text { does not granger cause } \log M 3\end{array}$ & 36 & $\begin{array}{l}3.432 \\
19.342\end{array}$ & $\begin{array}{l}0.045 \\
0.000\end{array}$ \\
\hline $\begin{array}{l}\text { logPER does not granger cause logBMPI } \\
\text { logBMPI does not granger cause logPER }\end{array}$ & 34 & $\begin{array}{l}0.061 \\
1.446\end{array}$ & $\begin{array}{l}0.941 \\
0.252\end{array}$ \\
\hline $\begin{array}{l}\text { logPER does not granger cause } \log M 3 \\
\text { logM3 does not granger cause logPER }\end{array}$ & 34 & $\begin{array}{l}2.116 \\
4.802\end{array}$ & $\begin{array}{l}0.139 \\
0.016\end{array}$ \\
\hline
\end{tabular}

\section{Conclusion}

With the caveat that our study face data availability and quality constraints, the study draws several conclusions. The paper has shed more light to what seems to have been marginalized in the discourses about the evolution of hyperinflation in Zimbabwe. First, the bidirectional relationship between the building materials price index and broad money, confirms the governor's claim that real estate dynamics, in cohorts with the banking sector, played a significant role in the shadow printing of money. Second, the existence of causality running from real estate price dynamics to consumer price index complements the first point. Third, the bidirectional causality between the consumer price index and money supply suggests a money supply-inflation spiral that cannot be explained with the Quantity Theory of Money approach. Fourth, the existence of long run relationships among the variables and convergent error correction mechanism within an ARDL framework sheds better light than existing unit root based approaches to establish cointegration. These findings are very important because the same trilateral relationship between the Zimbabwe Stock Exchange, parallel foreign exchange market and real estate market seem to continue to play a dominant role, in addition to monetary indiscipline, in the evolution of inflation dynamics in Zimbabwe. Currency manipulation by government sets the economy on a casino economy path in which unhealthy speculation in the three markets because the only way to preserve financial value. Once this casino is set in motion it hard to reverse and for this reason a permanent solution remains monetary reforms that include ways of ring-fencing the central bank from political rent extraction. The policy lesson from this paper is for government to manage expectations given the significance of adverse adaptive inflation expectations in Zimbabwe. Focusing on export performance and allowing interbank determination of exchange rates could be initial steps towards a sound currency.

\section{References}

Chitiga, M., \& Mabugu, R. (2008). Evaluating the impact of land redistribution: A CGE microsimulation application to Zimbabwe. Journal of African Economies, 17(4), 527-549.

Dawson, M., \& Kelsall, T. (2012). Anti-developmental patrimonialism in Zimbabwe. Journal of Contemporary African Studies, 30(1), 49-66.

Ellyne, M., \& Daly, M. (2013). Zimbabwe monetary policy 1998-2012: From hyperinflation to Dollarization1. Economic Management Under Hyperinflationary Environment: Lessons from Zimbabwe .Oxford University Press, 249-289.

Fundira, B. (2007). Money laundering in Zimbabwe, 2004 to 2006. Confronting the Proceeds of Crime in Southern Africa: An Introspection. ISS Monograph Series, (132), 47-72.

Gono, G. (2008). Zimbabwe's casino economy: Extraordinary measures for extraordinary challenges $\mathrm{ZPh}$ Publishers.

Gukurume, S. (2010). The politics of money burning and foreign currency exchange in Zimbabwe: A case study of Mucheke residents in Masvingo. Journal of Sustainable Development in Africa, 12(6), 62-73.

Gukurume, S. (2015). Livelihood resilience in a hyperinflationary environment: Experiences of people engaging in money-burning (kubhena mari) transactions in Harare, Zimbabwe. Social Dynamics, 41(2), $219-234$. doi:10.1080/02533952.2015.1069492

Kairiza, T. (2009). Unbundling Zimbabwe's journey to hyperinflation and official dollarization. Natl.Grad.Inst.Policy Stud.GRIPS, , 9.

Kararach, G., \& Otieno, R. O. (2016). Economic management in a hyperinflationary environment: The political economy of Zimbabwe, 1980-2008 Oxford University Press.

Kiguel, M. A., Lizondo, J. S., \& O'Connell, S. A. (1997). Parallel exchange rates in developing countries Springer. Madesha, W., Chidoko, C., \& Zivanomoyo, J. (2013). Empirical test of the relationship between exchange rate 
and inflation in Zimbabwe. Journal of Economics and Sustainable Development, 4(1), 52-58.

Makochekanwa, A. (2007a). A dynamic enquiry into the causes of hyperinflation in Zimbabwe. Transport, $9,8$.

Makochekanwa, A. (2007b). Zimbabwe's black market for foreign exchange. Journal of Economics, 98(1), 25-40.

Mawowa, S., \& Matongo, A. (2010). Inside Zimbabwe's roadside currency trade: The 'World bank' of Bulawayo. Journal of Southern African Studies, 36(2), 319-337.

McIndoe-Calder, T. (2018). Hyperinflation in Zimbabwe: Money demand, seigniorage and aid shocks. Applied Economics, 50(15), 1659-1675.

Mpofu, S., \& Nyamadzawo, J. (2016). Operations, regulation, and practices of the Zimbabwe stock exchange during the hyperinflationary period, 2000-08. Economic Management in a Hyperinflationary Environment: The Political Economy of Zimbabwe, 1980-2008, , 157-198.

Muñoz, M. S. (2007). Central bank quasi-fiscal losses and high inflation in Zimbabwe: A note International Monetary Fund.

Muñoz, S. (2006). Suppressed inflation and money demand in Zimbabwe International Monetary Fund.

Ndlovu-Gatsheni, S. J. (2015). Mugabeism?: History, politics, and power in Zimbabwe Springer.

Noko, J. (2011). Dollarization: The case of Zimbabwe. Cato J., 31, 339.

Palley, T. (2016). Financialization: The economics of finance capital domination Springer.

Pesaran, M.H. (2015). Time series and panel data econometrics Oxford University Press

Reserve Bank of Zimbabwe. (2007). Monetary Policy Statement. Government of Zimbabwe.

Reserve Bank of Zimbabwe. (2004). Monetary Policy Statement. Government of Zimbabwe.

Rupiya, M. (2011). The military factor in Zimbabwe's political and electoral affairs.

Sachikonye, L. M. (2003). From 'growth with equity' to 'fast-track' reform: Zimbabwe's land question. Review of African Political Economy, 30(96), 227-240.

Shumbambiri, G. (2016). Monetary policy formulation and implementation in a hyperinflationary environment. Economic Management in a Hyperinflationary Environment: The Political Economy of Zimbabwe, 19802008, , 336-378.

Tembo, J. (2016). Bank failures in Zimbabwe. Economic Management in a Hyperinflationary Environment: The Political Economy of Zimbabwe, 1980-2008, , 139-156. 